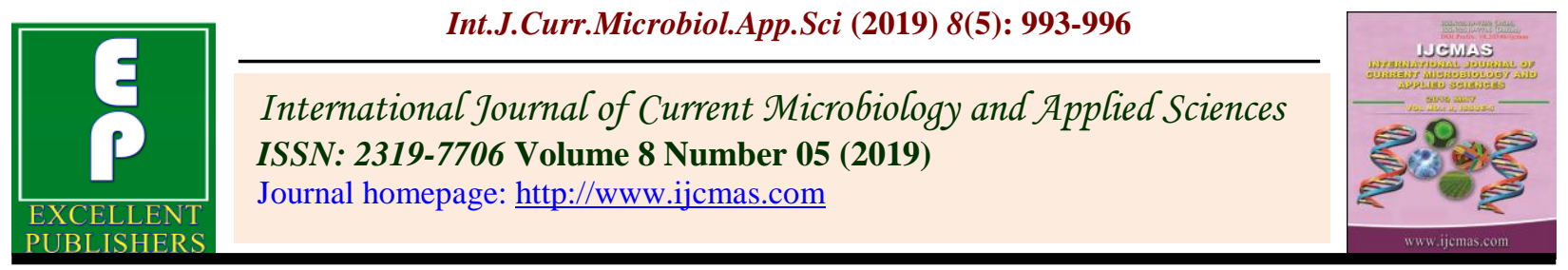

Original Research Article

https://doi.org/10.20546/ijcmas.2019.805.116

\title{
Rapid and Efficient Procedure for Genomic DNA Extraction from Trichoderma spp.
}

\author{
Tanvi P. Kadu*, Rajendra M. Gade, Jayant P. Rathod, Shyam Paraskar, \\ Bhushan Malghane and Arpit Shedmake
}

Vasantrao Naik College of Agricultural Biotechnology, Dr. Panjabrao Deshmukh Krishi

Vidyapeeth, Waghapur Road, Yavatmal-445001, Maharashtra, India

*Corresponding author

\begin{tabular}{|c|c|}
\hline & A B S T R A C T \\
\hline $\begin{array}{l}\text { K e y w o r d s } \\
\text { DNA, Trichoderma, } \\
\text { extraction, Purity }\end{array}$ & \multirow{3}{*}{$\begin{array}{l}\text { Molecular Biology experiments including gene cloning, restriction digestion, identification } \\
\text { by } 18 \mathrm{~S} \text { r-DNA requires purified and high quality genomic DNA. The major problems in } \\
\text { DNA isolation from fungus are impurities such as polysaccharides, protein and RNAs } \\
\text { which interfere in PCR reaction. In this study, proficient method for DNA extraction } \\
\text { without using liquid nitrogen, CTAB or lysozyme was optimized. The method utilizes very } \\
\text { few chemical compounds. The method involved crushing of fungal mycelia in lysis buffer } \\
\text { containing SDS, incubation at } 65^{\circ} \mathrm{C} \text {, extraction by chloroform, phenol and isoamyl alcohol } \\
\text { and finally DNA precipitation by cold ethanol. The results showed DNA with high yield } \\
\text { which can be utilized for PCR purposes. }\end{array}$} \\
\hline Article Info & \\
\hline $\begin{array}{l}\text { Accepted: } \\
\text { 15 April } 2019 \\
\text { Available Online: } \\
10 \text { May } 2019\end{array}$ & \\
\hline
\end{tabular}

\section{Introduction}

Trichoderma spp. enhances plant growth and productivity in several agricultural crops is important for the control of other fungal diseases such as soil and seed borne (Vazquez-Angulo et al., 2012). The use of Trichoderma spp. in the field can help to reduce the application of chemical pesticides and conserve the soil and its ecosystem. Thus Trichoderma cultures were isolated from soil of Yavatmal, Vidarbha region of Maharashtra to be used as local and adapted species for different crop plants. Identification of diverse species of Trichoderma isolated from soil is an important issue. Previously microorganisms were identified at species level by means of the application of the concept of Morphological species recognition i.e. MSR in combination with its other phonotypic traits. The visual identifications become highly error prone due to lack of well defined morphological characteristics in cultures. So to limit the above drawbacks DNA based characterization of isolates may reflects the clear picture of relationships than do morphological characters. Purified and high concentration of genomic DNA is a perquisite for taxonomic studies based on molecular characterization. Various authors described different methods for DNA isolation from Trichoderma (Gadambe et al., 2018; Vazquez-Angulo et al., 2012; Cassago et al., 2002). The major challenges for 
isolation of fungal DNA of good quality lies in breaking of rigid cell wall, high polysaccharide content and fungal nuclease (Fredrick et al.2005). All these methods include use of $\mathrm{CTAB}$, proteinase $\mathrm{K}$ (Wilson 1990), lysozyme (Flamm et al., 1984), high speed cell disruption (Muller, 1998) and liquid nitrogen (Lee et al., 1988).

The method described here for extracting genomic DNA from filamentous fungi did not use liquid nitrogen, $\mathrm{CTAB}$ or lysozyme for cell wall lysis and yielded DNA of high concentration without much affecting quality and purity. In this method we utilized 3\% SDS in lysis buffer and fungal mycelia were crushed in mortar and pestle without using liquid nitrogen. The DNA was extracted using solvent extraction method using phenol, chloroform, isoamyl alcohol and extracted in TE buffer.

\section{Materials and Methods}

\section{Cultures and growth conditions}

Six isolates of Trichoderma spp were isolated from the soil samples collected from different locations of Yavatmal, Maharashtra, India by serial dilution technique. Different isolates were grown on Potato dextrose broth (Table 1) and incubated for 3-4 days at $25 \pm 2{ }^{\circ} \mathrm{C}$ over incubator shaker at $120 \mathrm{rpm}$.

\section{DNA extraction}

Fungal mycelia of $250 \mathrm{mg}$ from six different isolates of Trichoderma spp. were crushed in $500 \mu \mathrm{l}$ of lysis buffer $(50 \mathrm{mM}$ Tris HCL, 50mM EDTA (pH 8.2), 3\% SDS) in mortar and pestle individually. After crushing macerate was transferred to $2 \mathrm{ml}$ labeled autoclaved micro centrifuge tube separately. $1 \mathrm{ml}$ of lysis buffer was added again in each tube and vortexed it for 2-3min and incubated at $65^{\circ} \mathrm{C}$ for 1 hour in water bath. $500 \mu$ of
Chloroform: phenol (1:1) was added to each tube and vortex briefly. Tubes were centrifuged at $14000 \mathrm{rpm}$ for $10 \mathrm{~min}$ at $4^{\circ} \mathrm{C}$ using cooling centrifuge (Eppendorf, Germany). The supernatant (aqueous layer) was collected in fresh labeled $1.5 \mathrm{ml}$ micro centrifuge tube with the help of micro pipette and $500 \mu \mathrm{l}$ of chloroform: isoamyl alcohol (24:1) was added to each samples. The tubes were inverted several times slowly and then centrifuge at $14000 \mathrm{rpm}$ for $5 \mathrm{~min}$ at $4^{\circ} \mathrm{C}$. Two distinct phases were observed from which supernatant was transferred in fresh autoclaved micro centrifuge tube without disturbing middle layer. Again $500 \mu \mathrm{l}$ of chloroform: Isoamyl alcohol (24:1) was added to the tubes and inverted several times and then centrifuge it at $14000 \mathrm{rpm}$ for $5 \mathrm{~min}$ at $4^{\circ} \mathrm{C}$. The aqueous phase was transferred to fresh $1.5 \mathrm{ml}$ micro centrifuge tube and ice chilled 100\% (absolute) ethanol was added and inverted the tubes gently for 2-3 min. The tubes were incubated for $30 \mathrm{~min}$ at $-20^{\circ} \mathrm{C}$ for DNA precipitation. The micro centrifuge tubes were centrifuge at $14000 \mathrm{rpm}$ for $5 \mathrm{~min}$ at $4^{\circ} \mathrm{C}$ and supernatant was discarded after centrifugation. $500 \mu 1$ of $70 \%$ chilled ethanol was added to the pellet of each tube and the tubes were inverted gently 4-6 times to wash the DNA pellet.

The tubes were again centrifuged at 14000 rpm for 3 min at $4^{\circ} \mathrm{C}$ and the supernatant was discarded with the help of micropipette. The tubes were then transferred to Vacuum evaporator (Eppendorf, Germany) and vacuum evaporated the ethanol for 2-5 mins depending on the amount of ethanol present in the microcentrifuge tube. $100 \mu \mathrm{l}$ of TE buffer (10 mM Tris base and $1 \mathrm{mM}$ EDTA, pH 8.4) was added to dissolve/resuspend the DNA. The tubes were incubated overnight at $37^{\circ} \mathrm{C}$ for complete resuspension and store at $-20^{\circ} \mathrm{C}$. The yield and purity of DNA was measured at 260, 280 and $230 \mathrm{~nm}$. 


\section{Results and Discussion}

The isolated genomic DNA was quantified by using spectrophotometric measurement (Eppendorf, Germany) at 260 and $280 \mathrm{~nm}$. The yield and purity of isolated DNA for six Trichoderma isolates in triplicate were noted in Table 2.

The present DNA extraction method yielded good quantity and quality of pure DNA. This DNA can be use for different applications. DNA data reflect the genotype of the organism and may give a clearer picture of relationships than do morphological characters. Polymorphism at the DNA level can be studied by several means, the most common of which is the analysis of restriction fragment length polymorphisms (RFLP), Amplified fragment length polymorphism (AFLP), Random amplified polymorphic DNA (RAPD), simple sequence repeats (SSR), etc. This method did not require liquid nitrogen (It can be difficult to procure in remote locations) or magnetic beads (tissue leaser) to crush the sample which is mostly unavailable to some undergraduate laboratories.

Table.1 Composition of potato dextrose broth

\begin{tabular}{|l|l|}
\hline Composition & g/l \\
\hline Potato infusion & 200 \\
\hline Dextrose & 20 \\
\hline Distilled water & $1000 \mathrm{ml}$ \\
\hline pH & $5.6 \pm 0.2$ \\
\hline
\end{tabular}

Table.2 Concentration and purity of genomic DNA isolated from six different isolates of Trichoderma spp.

\begin{tabular}{|c|c|c|c|}
\hline \multicolumn{2}{|c|}{ Isolates of Trichoderma } & \multirow{2}{*}{$\begin{array}{c}\begin{array}{c}\text { Concentration of DNA } \\
\left(\text { ng. } \mathbf{~ I ~}^{-\mathbf{1}}\right)\end{array} \\
852.8\end{array}$} & \multirow{2}{*}{$\begin{array}{c}\begin{array}{c}\text { Purity } \\
\text { (260/280 ratio) }\end{array} \\
2.01\end{array}$} \\
\hline T1 & T1-1 & & \\
\hline & T1-2 & 797.3 & 1.50 \\
\hline & T1-3 & 703.1 & 2.12 \\
\hline \multirow[t]{3}{*}{ T2 } & T2-1 & 270.4 & 1.52 \\
\hline & T2-2 & 137.7 & 1.73 \\
\hline & T2-3 & 340.0 & 1.58 \\
\hline \multirow[t]{3}{*}{ T3 } & T3-1 & 904.5 & 2.02 \\
\hline & T3-2 & 760.7 & 2.16 \\
\hline & T3-3 & 442.9 & 2.01 \\
\hline \multirow[t]{3}{*}{ T4 } & T4-1 & 234.1 & 1.60 \\
\hline & T4-2 & 522.6 & 1.16 \\
\hline & T4-3 & 335.9 & 1.86 \\
\hline \multirow[t]{3}{*}{ T5 } & T5-1 & 903.0 & 2.13 \\
\hline & T5-2 & 625.4 & 2.28 \\
\hline & T5-3 & 162.6 & 1.67 \\
\hline \multirow[t]{3}{*}{ T6 } & T6-1 & 157.9 & 2.10 \\
\hline & T6-2 & 362.3 & 1.12 \\
\hline & T6-3 & 425.1 & 1.15 \\
\hline
\end{tabular}

This method only required very simple instruments such as mortar and pestle, centrifuge machine and water bath. Certain hazardous chemicals like $\beta$-mercaptoethanol was also not used in our protocol and quality of DNA was also not got affected. This method is 
practicable for undergraduate students at laboratory level.

Problems in fungal DNA isolation are polysaccharids, protein and RNAs impurities which further interfere in PCR amplification. The purpose of this study was to simplify and improve the currently available genomic DNA extraction method from filamentous fungi (AlSamarrari and Schmidt 2000; Haugland et al., 1999). The isolated DNA amount and quality obtained by this method were suitable for the PCR amplification, restriction digestion and other molecular analysis. This method has several advantages such as no requirement of liquid nitrogen, low instrumentation requirement, the number of steps in extraction procedure is minimal, the initial material i.e. sample requirement is less and small amount of chemicals required. This method is comparatively simple and rapid method of fungal DNA extraction.

\section{References}

Al-Samarrari and Schmidt 2002.A simple method for extraction of fungal genomic DNA. Letter in applied Microbiology 30, 53-57.

Cassago A., Panepucci R, Baião A, HenriqueSilva F. 2002. Cellophane based miniprep method for DNA extraction from the filamentous fungus Trichoderma reesei. BMC Microbiol. 18, 2-14.

Flamm, R.K., Hinrichs D.K. and Thoma show M.F. 1984. Introduction of pAM beta-1 into Listeria monocytogenes by conjugation and homology between native $L$. monocytogenes plasmids. Journal of Bacteriology 2, 14.

Fredricks D.N., Smith C. and Meier 2005.A comparison of six DNA extraction methods for recovery of fungal DNA as assessed by quantitative PCR. Journal and clinical microbiology 43, 51225128.

Gadambe, S., Kale S. S., Kadu T. P., Toshy Agrawal and A.S. Kotasthane 2018. Molecular characterization of biocontrol isolates of Trichoderma aureoviridi. Journal of and Pharmacognosy Phytochemistry 2018; SP1: 2978-2983.

Haugland, R.A., Heckman J.L., Wymer L.J. 1999. Evalution of different methods for extraction of DNA from fungal conidia by qualitative competitive PCR analysis. Journal of Microbial methods 37, 165-168.

Lee, S.B., Milgroom, M.G. and Taylor, J.W. 1988. A rapid, high yield mini-prep method for isolation of total genomic DNA from fungi. Fungal Genet Newsl 35, 23- 24.

Muller, F.M., Werner K.E., Kasais M. and Francesconi 1998. A rapid extraction of genomic DNA from medically important filamentous fungi by high speed cell disruption. Journal of clinical microbiology 36, 1625-1629.

Vazquez-Angulo, J.C., Mendez-Trujillo, V., Gonzalez-Mendoza, D., Morales-Trejo, A., Grimaldo-Juarez, O., and CervantesDiaz, L. 2012. A rapid and inexpensive method for isolation of total DNA from Trichoderma spp (Hypocreaceae). Genetics and molecular research: GMR, 11(2), 1379-1384.

Wilson, K., 1990. Prepration of genomic DNA from bacteria In: Ausubel F M, Brent R. Current protocols in molecular biology, Greene publishing association and Wiley interscience, Yew York, Pp. 241245.

\section{How to cite this article:}

Tanvi P. Kadu, Rajendra M. Gade, Jayant P. Rathod, Shyam Paraskar, Bhushan Malghane and Arpit Shedmake. 2019. Rapid and Efficient Procedure for Genomic DNA Extraction from Trichoderma spp. Int.J.Curr.Microbiol.App.Sci. 8(05): 993-996.

doi: https://doi.org/10.20546/ijcmas.2019.805.116 